\title{
An Approach for Developing Optimal Sheep Carcass Chilling Method: A Comparative Case Study with Ambient Storage of Sheep Carcass
}

\author{
P. Vignesh*, R. Narendra Babu, Robinson J.J. Abraham, \\ Tensingh Gnanaraj, V. Govind and V. Appa Rao
}

Department of Livestock Products Technology (Meat science), Madras veterinary college, Chennai-7, Tamil Nadu Veterinary and animal sciences university, Tamil Nadu, India

*Corresponding author

\section{A B S T R A C T}

The focus of this study was to evaluate the effects of temperature variations on the quality of sheep carcass. For this sheep carcasses were subjected to existing practices followed during transportation and storage was simulated under different commercial and domestic storage temperatures like room temperature (simulating the retail outlet), chiller, display cabinet $\left(0-4^{\circ} \mathrm{C}\right)$ and slushed ice packed in thermocol box and also determined the effect of

\section{Keywords}

Sheep carcass, Quality, Retail meat, Physicochemical.

Article Info Accepted: 23 July 2017 Available Online: 10 September 2017 ambient conditions prevailed on quality of sheep carcasses in retail outlets in Chennai. Physico-chemical and microbial quality of the carcasses at different time intervals was assessed. A highly significant $(\mathrm{p}<0.01)$ difference in $\mathrm{pH}$ values was observed between different storage conditions and between storage periods. A rapid decrease in extract release volume was observed at room temperature followed by slushed ice packed in thermocol box. The total viable count of carcasses increased with increase in storage period and higher counts were observed at room temperature followed by chiller, display cabinet and slushed ice packed in thermocol boxes. Whereas in retails outlets, total viable count (TVC) of sheep carcasses ranged from 4.62 to $6.61 \mathrm{log} \mathrm{cfu} / \mathrm{g}$ of meat from $30 \mathrm{~min}$ to 6 hours at ambient temperature. Highly significant changes in weight loss of carcass, $\mathrm{pH}$ and extract release volume from 30 minutes to 6 hours at ambient temperature had been observed during the study. It can be interpreted from this study that quality of the carcass will be further deteriorated which leads to spoilage changes as evident from this study beyond six hours at ambient temperature. These results indicates building up of effective temperature control measures is indispensable during the supply chain of fresh sheep carcass cuts as a measure to reduce the spoilage changes as found in this study.

\section{Introduction}

Small ruminant sector plays an important role in the economy of the country with annual contribution of about Rs.24,000 million to rural and Rs.80,000 million to national economy of the country. Additionally sheep are considered as important tools for the development of rural poor and about 5 million families subsist on activities related to sheep rearing and utilizing their produce. Handling, processing and distribution of livestock produce provide livelihood for millions of people as well as providing valuable foreign exchange earnings to the country. The Indian meat industry is mainly based on production of fresh meat which is produced and sold daily. 
India has made many strides on production front but awfully lacking in the field of agricultural marketing. Presently marketing system in India suffers from number of constraints which are either infrastructure related or government regulation related or technology related. The growing purchasing power of the middle class is reflected in increased demand for meat, milk, eggs and fish. Market for meat as in the case of other livestock products is still largely unorganized, traditional and fragmented. These unorganized informal chains are unable to conform to safety standards thus enhancing the risk of contamination.

Meat is highly perishable; require immediate processing, storage and preservation hence processing and market linkages are therefore prerequisites for value creation and addition. The climate of Chennai, India is generally tropical as it is lying south of the Tropic of Cancer and nearing to equator. The average environmental temperature ranges from $38^{\circ} \mathrm{C}$ to $42^{\circ} \mathrm{C}$ during summer months (March-June) maximum temperatures of $30-32.4^{\circ} \mathrm{C}$ in winter months (November- January) has been reported in Chennai. Deterioration of carcass begins just after slaughtering as a result of microbiological, physical and chemical processes (Hedrick et al., 1994).The existing marketing infrastructure is far below the desired or required levels both in terms of capacity as well as quality of the facilities. Real time data on microbial and physicochemical quality of carcasses in retail outlets is scarce.

Temperature is one the important factor influencing physicochemical, microbial quality of meat and meat products. To slow the growth of microorganisms and extend shelf life of Meat products, the cold chain is widely used (Shin et al., 2010). The prime purpose of meat refrigeration is to slow the rate of bacterial growth (chilling) or to stop (freezing). If temperature reduced below optimal growth temperature of bacteria lag phase and generation time both increase. To attain final quality product and economic advantage, some factors like evaporative loss at different storage environment and drip loss need to be studied. The cold chain temperature maintenance operations include, display, chilled and frozen storage. Hence a study was taken up to assess the quality of sheep carcass cuts at different simulated conditions, which were common practices of Indian retailers and a study also has been taken up in mutton retail outlets, to assess the physicochemical and microbial quality of the carcasses at different time intervals maximum of six hours starting immediately after dressing the carcasses hanged at ambient temperatures in retail outlets for sale.

\section{Materials and Methods}

\section{Simulation studies at different storage conditions}

During initial phases of study trials of simulation work were carried out in the Department of Livestock Products Technology (Meat Science), Madras Veterinary College, Chennai. Carcass cuts of the animals were purchased from wholesaler in a slaughter house and transported to the department hygienically and were maintained under four different conditions viz., room temperature (simulating the retail outlet), chiller, display cabinet $\left(0-4^{\circ} \mathrm{C}\right)$ and slushed ice packed in thermocol box. The samples were stored under these conditions for a period of 8 hours and subjected to the following analysis 1) change in weight 2) $\mathrm{pH}$ 3) Extract Release Volume (ERV) 4) Product temperature 5) Total viable count at 30 minutes, 1, 2, 4, 6 and 8 hours.

The $\mathrm{pH}$ of meat sample was measured using a digital pH meter (Digisun Electronic System, Model: 2001).The extract release volume of meat samples were determined by the 
modified method of Pearson (1968). Total viable count of the meat samples were determined by the method described by American Public Health Association (APHA) (1984). Dehydrated media from HIMEDIA, Mumbai were employed for the microbial assessment. The meat samples (5 gram) were homogenized with $45 \mathrm{ml}$ of 0.1 percent sterile peptone water, using a sterile pestle and mortar to maintain an initial dilution of $10^{-1}$. Serial tenfold dilution was made up to $10^{-6}$ in pre-sterilized tubes containing $9 \mathrm{ml}$ of 0.1 percent peptone water. The sample preparation and plating were carried out under laminar flow chamber. The data was subjected to statistical analysis in SPSS software as per the standard procedure outlined by Snedecor and Cochran (1994) and the percentage values are presented in arcs in $\sqrt{ } \mathrm{P}$ values.

\section{Quality assessment at retail outlets}

Another study conducted to investigate the effect of the environmental temperature $\left({ }^{\circ} \mathrm{C}\right)$ and relative humidity (\%) at the retail outlet were recorded using Digital Thermo-Hygro Meter (HTC Make, India) and the average was calculated. The time taken at the retail outlet for the sale of the entire carcass after receipt was recorded. The weight loss in the carcass from the time of receipt of carcass till the entire carcass sold was recorded periodically at 30 minutes, 1 hour, 2 hour and 4 hours. The mutton meat samples from the retail outlet during summer and winter seasons were collected hygienically and transported in refrigerated containers immediately to the Department of Livestock Products Technology (Meat Science), Madras Veterinary College, Chennai and subjected to the analysis for following parameters 1) $\mathrm{pH}$, 2) Extract Release Volume (ERV) 3) Total Viable Count (TVC) at 30 minutes, 1, 2, 4 and 6 hour time intervals. The $\mathrm{pH}$ of meat sample was measured using a digital $\mathrm{pH}$ meter (Digisun Electronic System, Model:
2001).The extract release volume of meat samples were determined by the modified method of Pearson (1968). Total viable count of the meat samples were determined by the method described by American Public Health Association (APHA) (1984). Dehydrated media from Himedia, Mumbai were employed for the microbial assessment. The meat samples (5 gram) were homogenized with $45 \mathrm{ml}$ of 0.1 percent sterile peptone water, using a sterile pestle and mortar to maintain an initial dilution of $10^{-1}$. Serial tenfold dilution was made up to $10^{-6}$ in presterilized tubes containing $9 \mathrm{ml}$ of 0.1 percent peptone water. The sample preparation and plating were carried out under laminar flow chamber. The data was subjected to statistical analysis in SPSS software as per the standard procedure outlined by Snedecor and Cochran (1994) and the percentage values are presented in $\arcsin \sqrt{ } \mathrm{P}$ values.

\section{Results and Discussion}

\section{Simulation studies at different storage conditions}

\section{Product temperature}

In the present study, no significant difference in product temperature values was observed at room temperature condition between different storage periods. A highly significant $(\mathrm{p}<0.01)$ difference was observed at different storage condition and different storage periods. The carcass cuts kept at slushed ice packed in thermocol box had lower product temperature at 8 hours of storage followed by chiller, then display cabinet (Table 3 ).

\section{pH}

A highly significant $(\mathrm{p}<0.01)$ difference in $\mathrm{pH}$ values was observed between different storage conditions and between storage periods except at 30 minutes where no significant difference was observed (Table 1). 
The $\mathrm{pH}$ of sheep carcasses immediately after slaughter ranged from 5.76 to 6.59 and was in accordance with Bradeeba and Sivakumar (2013) who observed that the $\mathrm{pH}$ of mutton samples at retail outlet ranged from 5.20 to 6.70. The $\mathrm{pH}$ increase can be attributed to the rapid growth of spoilage microorganisms. According to Nizimani et al., (2008), in foods stored under aerobic conditions which are rich in protein and amino acids, it is common to increase the $\mathrm{pH}$ value as the count of spoilage bacteria increases, whose proteolytic activity results in the production of alkaline compounds.

During storage at room temperature it was observed that the $\mathrm{pH}$ values decreased up to 4 hours at room temperature where upon an increase was observed. This increase in $\mathrm{pH}$ at room temperature may be due to proliferation of surface microbes resulting in degradation of proteins and release of amino acids and other alkaline proteolysis products, as time increased the decreased the physicochemical composition of meat was observed.

However, in carcasses stored in chiller, display cabinet and slushed ice packed in thermocol boxes a consistent decline in $\mathrm{pH}$ was observed till 8 hours of storage. This can be attributed to lower microbial growth in carcasses stored at lower temperature and reduced rate of proteolysis.

\section{Extract release volume (ERV)}

A highly significant difference existed in extract release volume values between different storage conditions and a significant $(\mathrm{p}<0.05)$ difference between storage periods (Table 2). Extract release volume as a rapid test for detecting spoilage in meat and a mean ERV values of $24.6 \mathrm{ml}$ correlated with $\log 8$ bacterial number/ gram and concluded that ERV value of $25 \mathrm{ml}$ was supported as a divider between acceptable and unacceptable (James et al., 1964). During storage period, no significant difference in extract release volume was observed at 30 mins and highly significant difference was observed at 1, 2, 4, 6 and 8 hours of storage. A rapid decrease in extract release volume was observed at room temperature followed by slushed ice packed in thermocol box, whereas extract release volume values were similar in chiller and display cabinet stored carcasses. The decrease in extract release volume values at room temperature below $18 \mathrm{ml}$ at 8 hours of storage could be due to exposure of meat surface to bacterial contamination, whereas carcasses stored under controlled environment had better extract release volume due to the preservative effect of low temperature since it extends the lag phase of microbes.

\section{Microbial quality}

A highly significant $(\mathrm{p}<0.01)$ difference in total viable count was observed at different storage temperature and between storage periods (Table 4). The total viable count of carcasses increased with increase in storage period and higher counts were observed at room temperature followed by chiller, display cabinet and slushed ice packed in thermocol boxes.

The results are in agreement with Sachedev et $a l$. , (2002) who observed that total plate count significantly increased during longer storage period and the samples stored at room temperature revealed significantly higher counts compared to meat stored at refrigerated conditions. In the present study the TVC of carcasses stored at room temperature exceeded the limit of $\log 6$ at 8 hours of storage. The microbial quality was superior in carcass cuts stored in chiller, display cabinet followed by slushed ice packed in thermocol box. The reduced microbial load may be attributed to lower temperature which delayed the multiplication of microorganisms. 
Table.1 Mean \pm SE values of $\mathrm{pH}$ of sheep carcass cuts stored at different storage conditions $(\mathrm{N}=6)$

\begin{tabular}{|c|c|c|c|c|c|}
\hline & $\begin{array}{c}\text { Room } \\
\text { temperature }\end{array}$ & Chiller & Display cabinet & $\begin{array}{c}\text { Slushed ice } \\
\text { packed in } \\
\text { thermocol box }\end{array}$ & F value \\
\hline $\mathbf{3 0} \mathbf{~ m i n}$ & $6.57 \pm 0.01$ & $6.58 \pm 0.01$ & $6.59 \pm 0.01$ & $6.59 \pm 0.01$ & $0.328^{\mathrm{NS}}$ \\
\hline $\mathbf{1 ~ h r}$ & $6.24^{\mathrm{aE}} \pm 0.21$ & $6.47^{\mathrm{CE}} \pm 0.01$ & $6.37^{\mathrm{bE}} \pm 0.01$ & $6.37^{\mathrm{bE}} \pm 0.23$ & $149.768^{* *}$ \\
\hline $\mathbf{2} \mathbf{~ h r}$ & $6.03^{\mathrm{aC}} \pm 0.30$ & $6.37^{\mathrm{dD}} \pm 0.03$ & $6.29^{\mathrm{cD}} \pm 0.02$ & $6.19^{\mathrm{bD}} \pm 0.21$ & $626.504^{* *}$ \\
\hline $\mathbf{4 h r}$ & $5.76^{\mathrm{aA}} \pm 0.01$ & $6.26^{\mathrm{dC}} \pm 0.12$ & $6.17^{\mathrm{CC}} \pm 0.03$ & $6.06^{\mathrm{bC}} \pm 0.01$ & $671.121^{* *}$ \\
\hline $\mathbf{6 h r}$ & $5.94^{\mathrm{aB}} \pm 0.02$ & $6.15^{\mathrm{cB}} \pm 0.23$ & $6.05^{\mathrm{bB}} \pm 0.01$ & $5.95^{\mathrm{aB}^{\mathrm{B}}} \pm 0.03$ & $160.111^{* *}$ \\
\hline $\mathbf{8 h r}$ & $6.20^{\mathrm{dD}} \pm 0.01$ & $6.03^{\mathrm{CA}} \pm 0.01$ & $5.92^{\mathrm{bA}} \pm 0.01$ & $5.78^{\mathrm{AA}} \pm 0.01$ & $305.234^{* *}$ \\
\hline $\mathbf{F}$ value & $563.472^{* *}$ & $826.079^{* *}$ & $653.586^{* *}$ & $1425.406^{* *}$ & \\
\hline
\end{tabular}

$\mathrm{N}$ - Number of trials

Means bearing different superscript between columns (A, B, C) between rows ( $\mathrm{a}, \mathrm{b}, \mathrm{c})$ differ significantly $(\mathrm{p}<0.05)^{*}$ or $(\mathrm{p}<0.01) * *$

Table.2 Mean \pm SE values of Extract Release Volume $(\mathrm{ml})$ of sheep carcass cuts stored at different storage conditions $(\mathrm{N}=6)$

\begin{tabular}{|c|c|c|c|c|c|}
\hline & $\begin{array}{c}\text { Room } \\
\text { temperature }\end{array}$ & Chiller & Display cabinet & $\begin{array}{c}\text { Slushed ice } \\
\text { packed in } \\
\text { thermocol box }\end{array}$ & F value \\
\hline $\mathbf{3 0} \mathbf{~ m i n}$ & $39.91 \pm 0.37$ & $40.83 \pm 0.21$ & $40.33 \pm 0.21$ & $39.75 \pm 0.11$ & $3.870^{\mathrm{NS}}$ \\
\hline $\mathbf{1} \mathbf{~ h r}$ & $31.75^{\mathrm{aE}} \pm 0.25$ & $36.00^{\mathrm{dE}} \pm 0.12$ & $34.66^{\mathrm{cE}} \pm 0.10$ & $33.41^{\mathrm{bE}} \pm 0.20$ & $100.496^{* *}$ \\
\hline $\mathbf{2} \mathbf{~ h r}$ & $26.33^{\mathrm{aD}} \pm 0.16$ & $32.25^{\mathrm{dD}} \pm 0.25$ & $30.50^{\mathrm{cD}} \pm 0.18$ & $28.33^{\mathrm{bD}} \pm 0.16$ & $174.969^{* *}$ \\
\hline $\mathbf{4} \mathbf{~ h r}$ & $22.33^{\mathrm{aC}} \pm 0.16$ & $27.50^{\mathrm{dC}} \pm 0.18$ & $26.83^{\mathrm{cC}} \pm 0.10$ & $24.83^{\mathrm{bC}} \pm 0.10$ & $259.000^{* *}$ \\
\hline $\mathbf{6} \mathbf{~ h r}$ & $20.66^{\mathrm{aB}} \pm 0.16$ & $25.58^{\mathrm{dB}} \pm 0.20$ & $24.58^{\mathrm{cB}} \pm 0.20$ & $23.00^{\mathrm{bB}} \pm 0.12$ & $147.037^{* *}$ \\
\hline $\mathbf{8} \mathbf{~ h r}$ & $17.58^{\mathrm{aA}} \pm 0.20$ & $24.08^{\mathrm{dA}} \pm 0.15$ & $22.75^{\mathrm{cA}} \pm 0.35$ & $21.00^{\mathrm{bA}} \pm 0.22$ & $130.238^{* *}$ \\
\hline $\mathbf{F}$ value & $1244.396^{* *}$ & $1155.679^{* *}$ & $982.990^{* *}$ & $1899.544^{* *}$ & \\
\hline
\end{tabular}

N-Number of trials

Means bearing different superscript between columns (A, B, C) between rows ( $a, b, c)$ differ significantly $(\mathrm{p}<0.05)^{*}$ or $(\mathrm{p}<0.01) * *$

Table.3 Mean \pm SE of Product Temperature $\left({ }^{\circ} \mathrm{C}\right)$ values of sheep carcass cuts stored at different storage conditions $(\mathrm{N}=6)$

\begin{tabular}{|c|c|c|c|c|c|}
\hline & $\begin{array}{c}\text { Room } \\
\text { temperature }\end{array}$ & Chiller & Display cabinet & $\begin{array}{c}\text { Slushed ice } \\
\text { packed in } \\
\text { thermocol box }\end{array}$ & F value \\
\hline $\mathbf{3 0} \mathbf{~ m i n}$ & $28.75 \pm 0.24$ & $24.83^{\mathrm{bF}} \pm 0.13$ & $25.5^{\mathrm{cF}} \pm 0.19$ & $23.68^{\mathrm{aF}} \pm 0.10$ & $149.186^{* *}$ \\
\hline $\mathbf{1 h r}$ & $28.96 \pm 0.15$ & $15.05^{\mathrm{aE}} \pm 0.15$ & $20.20^{\mathrm{cE}} \pm 0.32$ & $16.73^{\mathrm{bE}} \pm 0.18$ & $816.180^{* *}$ \\
\hline $\mathbf{2} \mathbf{~ h r}$ & $28.83 \pm 0.21$ & $12.41^{\mathrm{bD}} \pm 0.09$ & $14.61^{\mathrm{cD}} \pm 0.14$ & $10.86^{\mathrm{aD}} \pm 0.15$ & $2790.39^{* *}$ \\
\hline $\mathbf{4 h r}$ & $29.18 \pm 0.20$ & $9.50^{\mathrm{bC}} \pm 0.14$ & $11.88^{\mathrm{CC}} \pm 0.12$ & $7.01^{\mathrm{aC}} \pm 0.10$ & $4519.98^{* *}$ \\
\hline $\mathbf{6 h r}$ & $28.71 \pm 0.10$ & $8.20^{\mathrm{bB}} \pm 0.07$ & $10.45^{\mathrm{CB}} \pm 0.09$ & $5.70^{\mathrm{aB}} \pm 0.10$ & $11828.09^{* *}$ \\
\hline $\mathbf{8 h r}$ & $28.83 \pm 0.16$ & $6.20^{\mathrm{bA}} \pm 0.10$ & $8.41^{\mathrm{CA}} \pm 0.09$ & $3.80^{\mathrm{aA}} \pm 0.13$ & $8251.80^{* *}$ \\
\hline F value & $0.85^{\mathrm{NS}}$ & $3035.62^{* *}$ & $1288.67^{* *}$ & $3139.04^{* *}$ & \\
\hline
\end{tabular}

$\mathrm{N}-\mathrm{Number}$ of trials

Means bearing different superscript between columns (A, B, C) between rows ( $a, b, c)$ differ significantly ( $<0.05)^{*}$ or $(\mathrm{p}<0.01) * *$ 
Table.4 Mean \pm SE of total viable count (log cfu per g) values of carcass cuts stored at different environment temperature conditions $(\mathrm{N}=6)$

\begin{tabular}{|c|c|c|c|c|c|}
\hline & $\begin{array}{c}\text { Room } \\
\text { temperature }\end{array}$ & Chiller & Display cabinet & $\begin{array}{c}\text { Slushed ice } \\
\text { packed in } \\
\text { thermocol box }\end{array}$ & F value \\
\hline $\mathbf{3 0}$ min & $2.82 \pm 0.01$ & $2.83 \pm 0.02$ & $2.84 \pm 0.01$ & $2.84 \pm 0.02$ & $1.41^{\mathrm{NS}}$ \\
\hline $\mathbf{1} \mathbf{~ h r}$ & $4.24^{\mathrm{dB}} \pm 0.12$ & $3.74^{\mathrm{aB}} \pm 0.02$ & $3.83^{\mathrm{bB}} \pm 0.13$ & $3.88^{\mathrm{cB}} \pm 0.32$ & $1515.11^{\text {** }}$ \\
\hline $\mathbf{2} \mathbf{~ h r}$ & $4.84^{\mathrm{dC}} \pm 0.21$ & $4.23^{\mathrm{aC}} \pm 0.12$ & $4.27^{\mathrm{bC}} \pm 0.16$ & $4.30^{\mathrm{CC}} \pm 0.25$ & $3006.697^{* *}$ \\
\hline $\mathbf{4} \mathbf{~ h r}$ & $5.31^{\mathrm{dD}} \pm 0.01$ & $4.41^{\mathrm{aD}} \pm 0.31$ & $4.57^{\mathrm{bD}} \pm 0.41$ & $4.65^{\mathrm{DD}} \pm 0.01$ & $5757.49^{* *}$ \\
\hline $\mathbf{6} \mathbf{~ h r}$ & $5.74^{\mathrm{dE}} \pm 0.01$ & $4.82^{\mathrm{aE}} \pm 0.01$ & $4.92^{\mathrm{bE}} \pm 0.32$ & $4.98^{\mathrm{cE}} \pm 0.05$ & $6380.21^{* *}$ \\
\hline $\mathbf{8} \mathbf{~ h r}$ & $6.22^{\mathrm{dF}} \pm 0.14$ & $5.14^{\mathrm{aF}} \pm 0.15$ & $5.22^{\mathrm{bF}} \pm 0.25$ & $5.57^{\mathrm{CF}} \pm 0.01$ & $1527.89^{* *}$ \\
\hline $\mathbf{F}$ value & $34352.03^{* *}$ & $15680.05^{* *}$ & $40284.583^{* *}$ & $32415.90^{* *}$ & \\
\hline
\end{tabular}

N-Number of trials

Means bearing different superscript between columns (A, B, C) between rows ( $\mathrm{a}, \mathrm{b}, \mathrm{c})$ differ significantly $(\mathrm{p}<0.05)^{*}$ or $(\mathrm{p}<0.01) * *$

Table.5 Mean \pm SE values of $\mathrm{pH}$, Extract Release Volume, Total Viable Count (TVC) of sheep carcass in retail outlet at ambient temperature during summer and winter season $(\mathrm{N}=12)$

\begin{tabular}{|c|c|c|c|c|c|c|}
\hline & \multicolumn{3}{|c|}{ WINTER } & \multicolumn{3}{c|}{ SUMMER } \\
\hline & $\mathbf{p H}$ & ERV (ml) & $\begin{array}{c}\text { TVC (log cfu } \\
\text { per g) }\end{array}$ & pH & ERV (ml) & $\begin{array}{c}\text { TVC (log cfu } \\
\text { per g) }\end{array}$ \\
\hline $\mathbf{3 0} \mathbf{~ m i n}$ & $6.54^{\mathrm{D}} \pm 0.01$ & $39.08^{\mathrm{E}} \pm 0.35$ & $4.62^{\mathrm{A}} \pm 0.01$ & $6.59^{\mathrm{E}} \pm 0.02$ & $38.12^{\mathrm{E}} \pm 0.15$ & $4.75^{\mathrm{A}} \pm 0.22$ \\
\hline $\mathbf{1 h r}$ & $6.27^{\mathrm{C}} \pm 0.24$ & $32.83^{\mathrm{D}} \pm 0.24$ & $4.92^{\mathrm{B}} \pm 0.42$ & $6.32^{\mathrm{D}} \pm 0.01$ & $31.62^{\mathrm{D}} \pm 0.20$ & $5.08^{\mathrm{B}} \pm 0.23$ \\
\hline $\mathbf{2} \mathbf{~ h r}$ & $5.97^{\mathrm{B}} \pm 0.01$ & $28.04^{\mathrm{C}} \pm 0.27$ & $5.32^{\mathrm{C}} \pm 0.26$ & $5.71^{\mathrm{A}} \pm 0.01$ & $27.33^{\mathrm{C}} \pm 0.19$ & $5.54^{\mathrm{C}} \pm 0.28$ \\
\hline $\mathbf{4} \mathbf{~ h r}$ & $5.72^{\mathrm{A}} \pm 0.21$ & $23.50^{\mathrm{B}} \pm 0.23$ & $5.71^{\mathrm{D}} \pm 0.35$ & $5.94^{\mathrm{B}} \pm 0.01$ & $22.12^{\mathrm{B}} \pm 0.21$ & $5.91^{\mathrm{D}} \pm 0.11$ \\
\hline $\mathbf{6} \mathbf{~ h r}$ & $5.97^{\mathrm{B}} \pm 0.01$ & $19.70^{\mathrm{A}} \pm 0.45$ & $6.34^{\mathrm{E}} \pm 0.11$ & $6.19^{\mathrm{C}} \pm 0.01$ & $18.16^{\mathrm{A}} \pm 0.31$ & $6.61^{\mathrm{E}} \pm 0.02$ \\
\hline F VALUE & $259.31^{* *}$ & $561.37^{* * *}$ & $786.64^{* *}$ & $422.52^{* *}$ & $1228.88^{* * *}$ & $2668.98^{* * *}$ \\
\hline
\end{tabular}

Means bearing different superscript between columns (A, B, C) between rows ( $a, b, c)$ differ significantly $(\mathrm{p}<0.05)^{*}$ or $(\mathrm{p}<0.01)$

Table.6 Mean \pm SE values of weight loss in sheep carcass kept at ambient temperature in retail outlet $(\mathrm{N}=15)$

\begin{tabular}{|c|c|c|c|c|c|c|c|}
\hline \multicolumn{4}{|c|}{ WINTER } & \multicolumn{3}{c|}{ SUMMER } \\
\hline Retail outlet & $\begin{array}{c}\text { Carcass } \\
\text { weight }\end{array}$ & $\begin{array}{c}\text { Weight loss in } \\
\text { grams }\end{array}$ & $\begin{array}{c}\text { Weight loss in } \\
\text { percentage }\end{array}$ & $\begin{array}{c}\text { Carcass } \\
\text { weight }\end{array}$ & $\begin{array}{c}\text { Weight loss in } \\
\text { grams }\end{array}$ & $\begin{array}{c}\text { Weight loss in } \\
\text { percentage }\end{array}$ & N \\
\hline $\begin{array}{c}\text { Dressed } \\
\text { weight }\end{array}$ & $8.898 \pm 0.32$ & - & - & $8.672 \pm 0.37$ & - & - & 15 \\
\hline $30 \mathrm{~min}$ & $8.803 \pm 0.32$ & $0.094^{\mathrm{D}} \pm 0.01$ & $\begin{array}{c}1.08 \pm 0.029 \\
(0.10 \pm 0.01)\end{array}$ & $8.572 \pm 0.37$ & $0.100^{\mathrm{D}} \pm 0.01$ & $\begin{array}{c}1.17 \pm 0.038 \\
(0.10 \pm 0.01)\end{array}$ & 15 \\
\hline $1 \mathrm{hr}$ & $8.754 \pm 0.32$ & $0.142^{\mathrm{A}} \pm 0.09$ & $\begin{array}{c}1.64 \pm 0.0529 \\
(0.12 \pm 0.02)\end{array}$ & $8.523 \pm 0.37$ & $0.148^{\mathrm{A}} \pm 0.08$ & $\begin{array}{c}1.75 \pm 0.057 \\
(0.13 \pm 0.02)\end{array}$ & 15 \\
\hline $2 \mathrm{hr}$ & $8.685 \pm 0.32$ & $0.210^{\mathrm{B}} \pm 0.01$ & $\begin{array}{c}2.43 \pm 0.83 \\
(0.15 \pm 0.02)\end{array}$ & $8.449 \pm 0.37$ & $0.221^{\mathrm{B}} \pm 0.01$ & $\begin{array}{l}2.62 \pm 0.087 \\
(0.16 \pm 0.02)\end{array}$ & 15 \\
\hline $4 \mathrm{hr}$ & $8.604 \pm 0.32$ & $0.290^{\mathrm{C}} \pm 0.06$ & $\begin{array}{c}3.35 \pm 0.11 \\
(0.18 \pm 0.03)\end{array}$ & $8.360 \pm 0.37$ & $0.310^{\mathrm{C}} \pm 0.04$ & $\begin{array}{l}3.67 \pm 0.123 \\
(0.19 \pm 0.03)\end{array}$ & 15 \\
\hline F Value & $0.117^{\mathrm{NS}}$ & $325.130^{* *}$ & & $0.102^{\mathrm{NS}}$ & $425.173^{* *}$ & & \\
\hline
\end{tabular}

Means bearing different superscript between columns (A, B, C) between rows (a, b, c) differ significantly (p<0.05)*

or $(\mathrm{p}<0.01)^{* *}$, Values in parentheses are $\operatorname{Arcsin} \sqrt{ } \mathrm{P}$ mean 


\section{Quality assessment at retail outlets}

Most of the carcasses in retail outlets were sold within six hours after slaughter as per preliminary study. The analysis of variance revealed a highly significant $(\mathrm{P}<0.01)$ difference in $\mathrm{pH}$, extract release volume, total plate count in sheep carcasses kept at ambient temperature in retail outlets during various time interval in winter as well as in summer season.

The mean \pm S.E values of weight loss $(\mathrm{Kg})$ of sheep carcasses kept in ambient temperature at $30^{\text {th }}$ minute, $1^{\text {st }}, 2^{\text {nd }}$ and $4^{\text {th }}$ hour were 0.094 $\pm 0.01,0.142 \pm 0.09,0.210 \pm 0.01$ and 0.290 \pm 0.06 respectively in retail outlets during winter season. The mean \pm S.E values of weight loss $(\mathrm{Kg})$ of sheep carcasses kept in ambient temperature for $30^{\text {th }}$ minute, $1^{\text {st }}, 2^{\text {nd }}$ and $4^{\text {th }}$ hour were $0.100 \pm 0.01,0.148 \pm 0.08$, $0.221 \pm 0.01$ and $0.310 \pm 0.04$ respectively in retail outlets during summer season were presented in table 5. The analysis of variance revealed a highly significant $(\mathrm{P}<0.0 .1)$ difference in weight loss of sheep carcasses at ambient temperature in different intervals in retail outlets in both winter and summer seasons. The fall in post-mortem $\mathrm{pH}$, of sheep meat during initial hours recorded in the present study might be due to biochemical changes occurs in the muscle tissue via anaerobic glycolysis produces a lactic acid build up (Nagaraj et al., 2005). The increase in the $\mathrm{pH}$ and extract release volume with longer period of exposure to ambient temperature of sheep carcasses in retail outlets may be attributed to microbial proliferation resulting in denaturation and breakdown of proteins as well as utilization of available moisture content in meat by microbes.

In the present study it was observed that the TVC of sheep carcasses ranged from 4.62 to $6.61 \mathrm{log} \mathrm{cfu} / \mathrm{g}$ of meat from $30 \mathrm{~min}$ to 6 hours at ambient temperature. The results are in agreement with Bradeeba and Sivakumar (2013) and Bhandare et al., (2007) who observed that sheep meat in retail outlets had TVC in the range of $4.90-7.08 \log 10 \mathrm{cfu} / \mathrm{gram}$ in Chidambaram and Mumbai respectively. The high levels of bacterial crosscontamination in the retail outlets may be due to initial bacterial load, infrastructure and poor transport conditions of carcasses from slaughter houses. However, these levels may tend to increase due to faulty handling practices if any by meat plant workers and the processing environment (Bell, 2001; Lawrie, 1998).

The per cent loss of weight in carcasses from 30 mins to 4 hours of storage ranged from 1.08 to 3.35 in winter and 1.17 to 3.67 in summer respectively. Irrespective of seasons with the increase in time between slaughter and sale the loss of weight in the carcasses also increased (Table 6). Comparative increase in weight loss during summer may be attributed to higher environmental temperature and the carcasses were exposed to external environment resulting in higher evaporative losses. These results indicate building up of effective temperature control measures is essential during the supply chain of fresh sheep carcass cuts. From results as shown in another study in retail meat outlets it can be concluded that existing conditions in retail outlets favours the rapid development of microbes and leads to other deteriorative physico-chemical changes which finally leads to spoilage of meat if storage time extended beyond six hours. Maintaining of cold chain is an effective measure to reduce the spoilage changes during transport, retail outlets and domestic storage.

\section{Acknowledgements}

This paper forms a part of the MVSc thesis of the first author submitted to the Tamil Nadu Veterinary and Animal Sciences University, Chennai, Tamil Nadu. 


\section{References}

Bell, R. G., 2001. Meat packaging: Protection, preservation and presentation. In Hui, Y. H., W.K. Nip, R.W. Rogers and O. A. Young (Eds.), Meat science and applications, USA: Marcel-Dekker, pp. 463-490.

Bhandare, S.G., A.T. Sherikar, A.M. Paturkar, V.S. Waskar and R.J. Zende, 2007.A comparison of microbial contamination on sheep/goat carcasses in a modern Indian abbatoir and traditional meat shops.Food Contr., 18: 854-858.

Bradeeba, K., and P.K. Sivakumaar, 2013.Assessment of microbiological quality of beef, mutton and pork and its environment in retail shops in Chidambaram, Tamil Nadu.Int. J. Pl. An and Env.Sci, 3(1):91-97.

Food and Agriculture Organization of the United Nations. Guidelines for Humane Handling, Transport and Slaughter of Livestock. Bangkok: FAO; 2001. http://www.fao.org/ DOCREP/003/X6909E/x6909e08.htm.

Hedrick, H.B., et al., Principles of meat science.3.ed.Dubuque: Kendall/Hunt Publishing, 1994. 354p.

James, M., Jay, Kalliopi and S. Kontou, 1964.Evaluation of the Extract release volume phenomenon as a rapid test for detecting spoilage in beef.Appl Microbiol, 12: 378-383.

Lawrie, R., 1998. Meat science (6th Ed.). Cambridge, UK: Woodhead.

Nagaraj, N.S., K.R. Anilakumar and K. Santhanam, 2006.Biochemical and physicochemical changes in goat meat during post-mortem aging.J Muscle Foods., 17: 198-213.

Nizimani, A. G., Paleologos, E.K., Savvaidis, I. N. and Kontominas, M.G. 2008. Formation of biogenic amines and relation to microbial flora and sensory changes in smoked turkey breast under various packaging conditions at $4{ }^{\circ} \mathrm{C}$. Food of Microbiology, 25:509-517.

Sachedev, A.K., A.S. Ram Gopal and V.K. Tanwar, 2002. Effect of seasons and storage conditions on the quality of cooked chicken stock. Indian J Poultry Sci., 37: 67-72.

Shin, J., Harte, B., Ryser, E. and Selke, S. 2010. Active packaging of fresh chicken breast, with allylisothiocyanate (AITC) in combination with modified atmosphere packaging (MAP) to control the growth of pathogens. Journal of Food Science 75:65-71.

Vision, 2050, National Research Centre on Meat, 2015, Indian council of Agricultural Research. New Delhi.

\section{How to cite this article:}

Vignesh, P., R. Narendra Babu, Robinson J.J. Abraham, Tensingh Gnanaraj, V. Govind and Appa Rao, V. 2017. An Approach for Developing optimal Sheep Carcass Chilling Method: A Comparative Case Study with Ambient Storage of Sheep Carcass. Int.J.Curr.Microbiol.App.Sci. 6(9): 2342-2349. doi: https://doi.org/10.20546/ijcmas.2017.609.287 